\title{
Beyond Textuality
}

\author{
AMY VILLAREJO
}

CORNELL UNIVERSITY

\section{Anna Cristina Pertierra and Graeme Turner \\ Locating Television: Zones of Consumption}

Routledge, New York, 2013

ISBN 978-0415509794

RRP US\$41.95

A collaboration between an anthropologist who has worked largely in Latin America and a widely published cultural studies scholar based in Australia, Locating Television makes an urgent plea for paying attention not only to the locatedness of television, but for the diverse, striated, uneven and contested spaces in which television takes place. Television, for these authors, compels us to analyses of what they call zones of consumption, a way of describing beyond mere textuality the various spatio-temporal scales of television's encounters, from television sets on display at the local mall to national and supra-national media industries.

At the heart of the book's contribution is an ethnography of television consumption conducted by Anna Cristina Pertierra in Chetumal, Mexico, a city at the ISSN 1837-8692

Cultural Studies Review 2014. ( 2014 Amy Villarejo. This is an Open Access article distributed under the terms of the Creative Commons Attribution 4.0 Unported (CC BY 4.0) License

(https://creativecommons.org/licenses/by/4.0/), allowing third parties to copy and redistribute the material in any medium or format and to remix, transform, and build upon the material for any purpose, even commercially, provided the original work is properly cited and states its license.

Citation: Cultural Studies Review (CSR) 2014, 20, 3993, http://dx.doi.org/10.5130/csr.v20i2.3993 
southern end of the state of Quintana Roo, almost on top of Belize's northern border. Chetumal is no cultural capital; to the contrary, in the most inspired traditions of cultural studies practitioners like the Birmingham Group, the authors selected a place cross-hatched with specific flows of everyday life somewhat removed from the culture industries, say, of Mexico City. A border town with a solid middle class, Chetumal provided a lively site for observing the way that television became enmeshed with daily activities on precisely the scales or zones of consumption that can differ widely depending upon where and how you look. For example, the television sets on display at the aforementioned local mall gave the authors a chance to conceive of 'browsing' these sets for sale as a way of engaging publicly with TV: the shoppers more squarely into middle-class patterns of consumption may no longer see flat-screen displays as objects of wonder, but they do provide 'aspirational models of new technologies' (40) as well as sites for interaction among peers (mostly young men). In dialogue with Anna McCarthy's work on public TV in Ambient Television, Pertierra and Turner don't disregard the role television has in domestic space but they resist generalising that space as the primary or only 'zone' of consumption for television worldwide. ${ }^{1}$

Indeed, one of the strongest arguments in Locating Television takes issue with the very universalising assumptions held (even if unwittingly) by many scholars and critics preoccupied with so-called convergence culture. That strain of thought, in the most basic terms, sees a number of consequences following from the replacement of broadcast television with multi-platform delivery and digital modes of consumption and use. Some wonder whether 'television' can remain the name for what we do with online platforms, leading to a series of reflections on whether television is dead or alive, or a series of inquiries about television's ontology: what, they ask, still and again, is television? Others have questioned whether post-broadcast television still plays a role in producing or perpetuating national culture, not only because-with time-shifting and narrowcasting-it has ceased to synchronise viewers in the 'time slot' but also because the transnational corporate culture industries adapt various products on a global market. (I myself have written about Viacom's simultaneous development of children's programming in China and queer programming in the United States.) ${ }^{2}$ Pertierra and Turner oppose the sometimes vacuous language of 'globalism' and 'convergence' with a call for situated, material, empirical studies of 
television practices, not just texts or even what John Caldwell calls 'production culture'. ${ }^{3}$ What is born from that call is this hybrid text of media anthropology and cultural studies, so that readers can see how the various scales or zones (from the domestic to the community to the national to the supra-national discourse of modernity) are themselves 'contigent, conjunctural, and instantiated'. (26)

The authors thereby provide a number of important correctives. They stress that broadcast television is by no means 'over' in many parts of the world, including Australia where they both work and where cable penetration is only about 30 per cent and there are strong forms of popular resistance to pay television. In the form of two opening anecdotes-one from Turner about news reporting during floods in his home state of Queensland, and one from Pertierra about reporting on the swine flu epidemic in Mexico-the authors stress that the real-time connectivity associated with television's liveness remains an important everyday effect, particularly in times of crisis. They also survey the critical literature on television in China (Curtin), Arab regions (Kraidy), Cuba (Rivero), and a host of other sites to demonstrate how television partakes as much of regional and even sub-regional scales as it does of the global, especially when one considers the legacies of imperialist media practices and the ways television industries position themselves in relation to the West. By introducing the key idea of the 'zone,' they want to suggest that spatio-temporal scales are adaptable and fungible, and not tied to previous abstractions of domesticity or nation (or even region or locale), depending upon the context and specific locatedness of television's taking place.

As I read Locating Television, I found myself accepting that my own norms and assumptions derive largely from US and UK television, the two national scenes that have produced the bulk of scholarship in television studies in the English language. There are reasons for this, having to do with the way our respective academic fields in cinema and media studies have grown and fed academic publishing. As many of our colleagues have shown us, we need to unlearn our privilege even as we practise our own locatedness. But there is something strident in Pertierra and Turner's tone regarding their own contribution: it starts to feel as though they are beating a dead horse when they insist that their book 'rubs against the grain' (17) of most television scholarship, or that its opening chapter does 'a little more than the usual scene setting' (41) 
In fact, there is very little quantitative evidence of the actual ethnography, the 'immersive research of participant observation', (29) that would appear to be this volume's most significant original research and evidentiary basis. In Chapter 1 , where the material first appears, we have five pages and four photos, while Chapter 2 provides merely contextual material about Mexican television and Chapter 4, at twenty-four pages with five photos, contributes the bulk of the ethnographic account. There is no doubt the rest of the book provides a useful survey or overview of the many angles through which this core research might be illuminated, but it is more valuable perhaps to a student unfamiliar with, say, the development of media anthropology over the past few decades, or the treatment of 'everyday life' in cultural studies. For academic colleagues of Pertierra and Turner, whether media scholars or anthropologists, these sections may feel as maddeningly terse and simplified as they did to this reader. Likewise, the assumptions Pertierra and Turner make about the state of the field of cinema and media studies seem out of whack to me. Many of us in the field (Brian Larkin, Lisa Parks, Bhaskar Sarkar, Rosalind Morris and Elizabeth Povinelli to name but a few) are not at all anxious about how the disciplines of anthropology and cultural studies police their own boundaries. It might also be worth mentioning how important feminist and queer strains of research have been to the fieldwork and studies they cite (Lisa Rofel, Yeidy Rivero, Anna McCarthy, Ana López, again to name a few), but those two important critical genealogies are largely downplayed in the book's review sections.

In summary, Locating Television is a window onto a fascinating research project about which one wishes to learn more. It might stimulate further projects organised to give us the most nuanced, located and precise observations about television's place and role in our worlds-from the little worlds of living rooms and pubs and malls to those big abstractions of nation and globe which deserve much greater scrutiny.

Amy Villarejo is a professor in and chair of the Department of Performing and Media Arts at Cornell University, where she also is appointed in the Feminist, Gender, and Sexuality Studies Program. Her most recent book is Ethereal Queer: Television, Historicity, Desire (2014). 


\section{-NOTES}

${ }^{1}$ Anna McCarthy, Ambient Television: Visual Culture and Public Space, Duke University Press, Durham, 2001.

2 Amy Villarejo, Ethereal Queer: Television, Historicity, Desire, Duke University Press, Durham, 2014 .

${ }^{3}$ John Thornton Caldwell, Production Culture: Industrial Reflexivity and Critical Practice in Film and

Television, Duke University Press, Durham, 2008.

\section{-BIBLIOGRAPHY}

McCarthy, A., Ambient Television: Visual Culture and Public Space, Duke University Press, Durham, 2001. doi: http://dx.doi.org/10.1215/9780822383130

Villarejo, A., Ethereal Queer: Television, Historicity, Desire, Duke University Press, Durham, 2014 .

Thornton Caldwell, J., Production Culture: Industrial Reflexivity and Critical Practice in Film and Television, Duke University Press, Durham, 2008. doi: http://dx.doi.org/10.1215/9780822388968 